\title{
In Memory of Alla Vasil'evna Kulagina
}

Folklore scholars and pedagogues are saddened by the loss on October 20, 2009 of Alla Vasil'evna Kulagina, Professor in the Department of Folklore (кафедра устного народного ворчества) of Moscow State University's Philological Faculty (филологический факультет). Alla Vasil'evna was born on January 27, 1938 in Selo Khorol', Primorskii krai of Russia's Far East. Her only sibling was her brother, Felix. From 1972 to the time of her death, Professor Kulagina studied and taught at Moscow State University. She was beloved by colleagues and students alike.

Professor Kulagina specialized in the ballad, chastushka, lyric songs, and folktales. Her dissertation topic was "The Russian Folk Ballad As a Genre" (Русская народная баллада как жанр, 1974), and she wrote a textbook entitled The Russian Folk Ballad (Русская народная баллада, 1977).

Alla Vasil'evna was an enthusiastic collector and scholar of the chastushka at a time when the genre in its contemporary form (the urban political and indecent chastushka) was out of favor and politically dangerous to explore. She committed hundreds of chastushki to memory and was accustomed to sing out a chastushka appropriate to the situation. Her monograph, The Poetic World of the Chastushka (Поэтический мир частушки, 2000), and her collection, Chastushki From Nerekhta (Нерехтинские частушки, 1993), bear witness to this interest. In addition, chastushki are included in Vetluzhskaia Land (Ветлужская сторона, 1996), a collection of calendar and family ceremonial folklore, spells, ballads, and spiritual verses that she compiled with the participation of her graduate student, Vasilii Aleksandrovich Kovpik.

Other collections include the well-received Urban Songs, Ballads, and Romances (Городские песни, баллады и романсы, 1999) and the impressively complete and detailed two-volume Russian Wedding (Русская свадьба, 1999 and 2001), co-authored with A. N. Ivanov. The collection includes stories about the wedding ritual, laments, and ritual songs. Alla Vasil'evna's most recent collection was Orthodox Priests as Collectors of Russian Folklore (Православные священники собиратели русского фольклора, 2004), co-authored with V. G. Smolitskii.

Alla Vasil'evna authored an impressive quantity of textbooks. A partial list includes the anthologies Slavic Folklore (Славянский фольклор, 1987) and Russian Oral Folklore (Русское устное народное 
творчество, 1996), as well as a teachers' aide entitled Russian Oral Folklore (Русское устное народное творчество, 1995). Her reader, Russian Oral Folklore (Русское устное народное творчество: хрестоматия, 1996) has long been used as the basic text for the folklore course at The University of the Russian Academy of Education, where Alla Vasil'evna also taught.

Her articles include "The Character of the Tragic in Folk Ballads" (Характер трагического в народных балладах), Izvestiia OLIA AN SSSR (Известия ОЛИЯ АН СССР, vol. 33 (Moscow, 1974) and "Parallelism and Symbolism in the Chastushka" (Параллелизм и символика в частушках), Fol'klor kak iskusstvo slova, no. 5 (MGU, 1981). She also wrote articles that were included in books, such as "Folklore and Russian Culture" (Фольклор и русская культура), in Russkaia drevniaia kul'tura (MGU, 1995) (Русская древняя культура, МГУ) and the introductory article in the bilingual reader, Russian Folktales (Русские сказки, 1984).

Professor Kulagina presented papers at several international conferences in Minsk, Bulgaria, Slovenia, Syktyvkar, Moscow, Archangel, and Petrozavodsk. She has written articles regularly for the journals, Zhivaia starina (Живая старина), Narodnoe tvorchestvo (Народное творчество), and Moscow State University's Vestnik (Вестник Московского государственного университета).

Alla Vasil'evna will be remembered fondly in the hearts of everyone who knew her. She was daring in her research choices, and she had a magnanimous, appealing personality. From 1969 to 2009 she took her students on folklore collecting expeditions into the heart of Russia to Kostroma, Kaluga, Nizhnii Novgorod, Vologda, and Arkhangel'sk oblast'. Her good will, kindness, and humor sustained various groups over the years. She worked laboriously archiving the collected materials and putting the material of earlier MGU expeditions into order.

In 1975 during the Cold War era, Alla Vasil'evna fearlessly volunteered to teach a seminar for American teachers at MGU for the IREX Exchange of Teachers with the Soviet Union, despite the fact that at the time Americans were referred to as provocateurs. Her seminar was the one most popular with the American teachers, and it remained so for many years.

The impression that Alla Vasil'evna Kulagina made on colleagues, friends, and students is unforgettable. Her death has left an empty place in our hearts, a place that had been previously filled by Alla's larger than life personality. Alla Vasil'evna was laid to rest on Monday, October 26, 
2009 in Vostriakovskoe Cemetery in Moscow. She will be sorely missed. May the earth be gentle to her (земля ей пухом).

Bonnie Marshall

New Hampshire Historical Society's Museum

Museum of Russian Icons

Meredith, NH

USA 